\section{Potential for the Improvement of Turf Quality in Crested Wheatgrass for Low-maintenance Conditions}

\author{
Joseph G. Robins ${ }^{1}$ and Blair L. Waldron \\ USDA-ARS Forage and Range Research Laboratory, 6300 Old Main Hill, \\ Utah State University, Logan, UT 84322-6300
}

Paul G. Johnson

Department of Plants, Soils, and Biometeorology, Utah State University, Logan, UT 84322

Additional index words. crested wheatgrass, genotypic correlation, heritability, turfgrass, turf quality

\begin{abstract}
With the exception of the undesirable characteristic of summer dormancy and the accompanying low aesthetic value, crested wheatgrass has many desirable characteristics in semiarid environments, making it a promising candidate for lower water use turf. Using a population of 27 half-sib families, this study characterized the underlying genetics of turf quality (based on a 1-9 rating scale) of crested wheatgrass and compared the performance of crested wheatgrass turf with traditional control cultivars ('Cody' buffalograss, 'Gazelle' tall fescue, 'Manhattan 3' perennial ryegrass, and 'Midnight' Kentucky bluegrass) over 2 years under space-planted conditions. Heritability estimates were generally high $\left(h^{2}=0.44\right.$ to 0.84$)$ and suggested a strong additive genetic component for crested wheatgrass turf quality throughout the summer months. Genotypic correlations among the monthly turf quality scores were very high (greater than 0.90) indicating a strong commonality for the genetics underlying turf quality during any point in the growing season. Thus, a breeding program aimed at improving turf quality in this population of crested wheatgrass would stand a good chance for success. However, primarily as a result of summer dormancy, the crested wheatgrass turf performed poorly compared with the control cultivars during late spring and early summer. Turf quality scores in early July were $\approx 3$ for the crested wheatgrass half-sib families compared with scores between 5 and 6 for the traditional turf species. Thus, crested wheatgrass, for the near future, will likely be a viable turf candidate only in situations in which turf aesthetics are secondary to a desire for low-input requiring species.
\end{abstract}

As water resources in many areas, but particularly the western United States, become more limiting and are sought by competing interests, there is a need for turfgrass species that require less irrigation for low-maintenance situations (Feldhake et al., 1983). The need to identify new lower waterrequiring turfgrass species has resulted in the characterization of many perennial grass species for turfgrass potential (Diesburg et al., 1997), including crested wheatgrass [Agropyron cristatum (L.) Gaertn.]. Crested wheatgrass is a perennial Triticeae grass species, is well suited to harsh semiarid conditions, and is a key species for revegetation and forage production on rangelands of the Great Plains and intermountain regions of the United States (Asay and Jensen, 1996).

\footnotetext{
Received for publication 30 Apr. 2007. Accepted for publication 1 July 2007.

Joint contribution of the USDA-ARS and the Utah Agr. Exp. Stat. Paper No. 7906.

Mention of a trademark, proprietary product, or vendor does not constitute a guarantee or warranty of the product by the USDA or Utah State University. ${ }^{1}$ To whom reprint requests should be addressed; e-mail joseph.robins@usu.edu.
}

Several studies have investigated the potential (Bushman et al., 2007; Diesburg et al., 1997; Hanks et al., 2006; Robins et al., 2006) and breeding (Asay et al., 1999; Hanks et al., 2005) of crested wheatgrass for turf. 'RoadCrest' was the first crested wheatgrass cultivar specifically developed for turf use (Asay et al., 1999), although other cultivars such as 'Ephraim' (Stevens et al., 1983) and 'Fairway' (Kirk, 1932) are commonly used in roadside stabilization and other lowmaintenance turf situations. Breeding efforts are ongoing for further crested wheatgrass turf improvements.

A potential roadblock to higher public acceptance of crested wheatgrass turf is its poorer performance for turf characteristics such as color, quality, and increased tendency for summer dormancy when compared with traditional turf species (Bushman et al., 2007; Robins et al., 2006). Turf quality is a particularly important trait and consists of the combination of color intensity, leaf texture, and tiller density (Gibeault et al., 1989; Skogley and Sawyer, 1992) and can be affected by pest resistance. Hanks et al. (2005) identified the rapid spring growth and reduced summer turf quality as the most limiting characteristics of crested wheatgrass for turfgrass. However, the study also identified high levels of broad-sense heritability for turf quality and suggested that breeding efforts aimed at increasing crested wheatgrass turf quality would be successful (Hanks et al., 2005). Although high broad-sense heritabilities suggest the importance of genetic as compared with environmental factors (Holland et al., 2003; Nyquist, 1991), they are not indicative of the potential that can be made in a breeding program.

The objective of this study was the estimation of genetic variation and narrow-sense heritability for turf quality in a population of half-sib families. These families represent breeding materials used in ongoing efforts at improving turf-quality traits in crested wheatgrass for low-maintenance turfgrass conditions.

\section{Materials and Methods}

Plant materials. Plant materials consisted of 27 half-sib crested wheatgrass families and six control cultivars representing various turfgrass species. The half-sib families came from the polycross nursery of 27 crested wheatgrass genotypes selected from 'RoadCrest' crested wheatgrass (Asay et al., 1999). Selection criteria were spreading ability, short growth stature, and fine leafiness. The six control cultivars were 'Cody' buffalograss [Buchloë dactyloides (Nutt.) Engelm.] (Severmutlu et al., 2005), 'Fults' weeping alkaligrass [Puccinellia distans (L.) Parl.] (identified by S.E. Metsker in 1979), 'Gazelle' tall fescue (Festuca arundinacea Schreb.) (Rutgers University and Pure Seed Testing, Inc.), 'Manhattan 3' perennial ryegrass (Lollium perenne L.) (Rose-Fricker et al., 2002), 'Midnight' Kentucky bluegrass (Poa pratensis L.) (Meyer et al., 1984), and 'RoadCrest' crested wheatgrass.

Experimental design. The study location was the Utah Agricultural Experiment Station Evans Farm in Millville, UT $\left(41^{\circ} 45^{\prime} \mathrm{N}\right.$, $111^{\circ} 8^{\prime} \mathrm{W}$; $1350 \mathrm{~m}$ above sea level; Nibley silty clay loam [fine, mixed, mesic Aquic Argiustolls]). The experimental design was a randomized complete block design with four complete blocks. Transplanting of the control cultivars and half-sib families occurred in Apr. 1999. Individual plots consisted of 10 plants. Spacings were $1 \mathrm{~m}$ between rows and $0.5 \mathrm{~m}$ between plants within a row. Although sward plots would have been preferable to space-planted plots for the evaluation of turf quality, the polycross used to derive the halfsib families did not result in sufficient seed production for a sward plot study. Thus, seed limitations required the utilization of spaceplanted plots. Space-planted plots have been used previously to characterize turf quality (Hanks et al., 2005).

Throughout the study, irrigation occurred weekly from April to October at 50\% evapotranspiration $\left(\mathrm{ET}_{0}\right)$ replacement. Approximate $\mathrm{ET}_{0}$ values for turfgrass at Millville, UT, were: April, $48 \mathrm{~mm}$; May, $87 \mathrm{~mm}$; June, $109 \mathrm{~mm}$; July, $121 \mathrm{~mm}$; August, $107 \mathrm{~mm}$; September, $68 \mathrm{~mm}$; and October, $29 \mathrm{~mm}$ 
(Hill and Kopp, 2002). Throughout the evaluation, plots were mowed at a height of 7.62 $\mathrm{cm}$ (3.0 in) with a rotary mower at an interval that removed $\approx 33 \%$ of growth at each mowing. The clippings were left on the ground and $49 \mathrm{~kg} \cdot \mathrm{ha}^{-1}$ of nitrogen $\left(1 \mathrm{lb} 1000 \mathrm{ft}^{-2}\right)$ was applied in early June and again in September.

Phenotypic data collection and analysis. Data collection took place from April through October in both 2000 and 2001. However, data were not collected during May 2001. Turf quality was measured monthly and twice in July during these time periods. The turf quality assessment combined visual ratings of color intensity, leaf texture, and tiller density (Gibeault et al., 1989; Skogley and Sawyer, 1992). Ratings followed a 1 to 9 scale. A score of 9 was given to the plot with the highest turf quality in the study and indicated a plot with solid green color, fine leaves, and dense sod with solid groundcover. A score of 5 was given to plots with acceptable turf quality and indicated a plot with uniform, mostly green color, acceptable leaf fineness, and a uniform sod with little openground area. A score of 1 was given to plots with unacceptable turf quality and indicated a plot with brown color, coarse leaves, and an open canopy. Other values were given to plots with characteristics intermediate to these descriptions.

Using the MIXED (Littell et al., 1996) and IML procedures of SAS (SAS Institute, 2006), variance components and heritabilities with their standard errors were computed with control genotypes removed from the analysis (Holland et al., 2003) based on a split-plot-in-time modification of the randomized complete block design with four complete blocks. The model used was appropriate for the analysis of genetic variation and heritability in a set of half-sib families (Nguyen and Sleper, 1983) based on entry means and was as follows:

$$
h^{2}=\frac{\sigma_{H S F}^{2}}{\sigma_{H S F}^{2}+\frac{\sigma_{H S F Y}^{2}}{y}+\frac{\sigma_{H S F R}^{2}}{r}+\frac{\sigma_{\varepsilon}^{2}}{y r}}
$$

where,

$\sigma_{H S F}^{2}=$ variation among half-sib families;

$\sigma_{H S F Y}^{2}=$ variation resulting from the half-sib family-by-year interaction;

$$
\begin{aligned}
\sigma_{H S F R}^{2}= & \text { variation resulting from the } \\
& \text { half-sib family-by-replication } \\
& \text { interaction; }
\end{aligned}
$$

$$
\sigma_{\varepsilon}^{2}=\text { residual variation; }
$$

and $y$ and $r$ were the number of years and replications, respectively.

To compare the performance of the halfsib families with that of the control cultivars, a second model was used to calculate mean scores for each entry. This model considered genotypes (half-sib families and cultivars), years, and the genotype-by-year interaction to be fixed effects and block effects and interactions to be random. Genotypic correlations (with corresponding standard errors) between the monthly turf quality scores were also calculated using the MIXED and IML procedures of SAS and with the control cultivars removed from the analysis (Holland, 2006).

\section{Results and Discussion}

Genetic variation and heritability of turf quality. Although the main effect resulting from year was generally a significant term in the model, the half-sib family-by-year interaction only differed from zero during the late July rating period (Table 1) and in that instance was roughly three times smaller than the corresponding half-sib family variation estimate. Thus, genotypeby-environment (half-sib family-by-year) interaction was negligible or nonexistent in this study, and all further discussion and conclusions are based on data combined across years. Additionally, there was no indication that pest damage played a role in the characterization of turf quality and, thus, is not further discussed.

Variation among the half-sib families (additive genetic variation) was present during each of the months except April (Table 1). Although there was no test for determining differences among the monthly half-sib family variation values, generally, the variation among half-sib families increased from the spring to summer and then decreased during the fall. The numerically highest values occurred in August and September (Table 1). Apparently, the maximization of genetic differences among the half-sib families required more stressful, hotter summer months with smaller differences during the less stressful spring and fall time periods.

Monthly turf quality heritability estimates were low to moderate based on a plot basis but were moderate to high on the entry mean basis (Table 1). As would be expected based on the trend in half-sib family variation values over the course of the summer, heritability estimates increased from the spring to summer and then decreased going into fall with August being the month with the numerically highest heritability $\left(h^{2}=0.84\right)$. Across the entire growing season, heritabilities were suggestive of strong genetic control of turf quality with only June and October having estimates less than 0.60 . These high estimates of turf quality heritability are well in line with previous high estimates of broad-sense heritability of turf quality in crested wheatgrass (Hanks et al., 2005) and high estimates of turf trait heritabilities in other species such as bermudagrass [Cynodon dactylon (L.) Pers.; Wofford and Baltensperger, 1985] and perennial ryegrass (Waldron et al., 1998).

The high turf quality heritability estimates suggested that turf quality, at least in this population of half-sib families under the conditions of this study, was under very strong genetic as opposed to environmental control. Thus, selection for improved crested wheatgrass turf quality in this population of half-sib families should be successful. However, testing at additional locations is necessary before genotype-by-environment interaction can be completely disregarded.

Comparison of half-sib families to control cultivar turf quality. Although generally lower than the control cultivars, the mean turf quality of the crested wheatgrass halfsib families performed favorably with the control cultivars during the months of April, September, and October (Table 2). The main problem with crested wheatgrass turf quality occurs during the hotter summer months when, despite irrigation and fertilization, crested wheatgrass enters dormancy (Bushman et al., 2007; Robins et al., 2006). This was illustrated in this study by low turf quality scores of the half-sib family means during the June to August/September time period (Table 2). During these months particularly, the performance of the half-sib families was much lower than that of most of the control cultivars. However, the crested wheatgrass half-sib families always outperformed, at least numerically, the more typical low-maintenance turf cultivars, 'Fults' alkaligrass and 'RoadCrest' crested wheatgrass (Table 2). This result suggested the success of selecting for improved turf traits in this crested wheatgrass population because these half-sib families originated from 'RoadCrest'.

Eight of the half-sib families had higher turf quality scores than the mean half-sib family score in at least one of the months of the study (Table 2). Two half-sib families,

Table 1. Estimates of the half-sib family and half-sib family-by-year interaction, variance components, and narrow-sense heritability estimates, \pm SE of estimates, for the crested wheatgrass half-sib families monthly turf quality scores managed under deficit irrigation from 2000 to 2001.

\begin{tabular}{lcccc}
\hline Month & $\sigma_{\text {half-sib family }}^{2}$ & $\sigma_{\text {half-sib family by } \mathrm{yr}}^{2}$ & $\mathrm{~h}^{2}{ }_{\text {Plot Basis }}$ & $\mathrm{h}^{2}$ Entry Mean \\
\hline April & $\mathrm{NS}$ & $\mathrm{NS}$ & $\overline{-}^{\mathrm{z}}$ & - \\
June & $0.03 \pm 0.02$ & $\mathrm{NS}$ & $\mathrm{NS}$ & $0.44 \pm 0.22$ \\
Early July & $0.13 \pm 0.05$ & $\mathrm{NS}$ & $0.37 \pm 0.10$ & $0.77 \pm 0.10$ \\
Late July & $0.17 \pm 0.07$ & $0.05 \pm 0.03$ & $0.36 \pm 0.10$ & $0.72 \pm 0.10$ \\
August & $0.40 \pm 0.12$ & $\mathrm{NS}$ & $0.47 \pm 0.09$ & $0.84 \pm 0.06$ \\
September & $0.27 \pm 0.09$ & $\mathrm{NS}$ & $0.39 \pm 0.09$ & $0.82 \pm 0.08$ \\
October & $0.11 \pm 0.06$ & $\mathrm{NS}$ & $\mathrm{NS}$ & $0.52 \pm 0.19$ \\
Average & $0.11 \pm 0.04$ & $\mathrm{NS}$ & $0.38 \pm 0.09$ & $0.80 \pm 0.07$
\end{tabular}

${ }^{\mathrm{z}}$ Heritability was not calculated for April as a result of the nonsignificant genetic variation.

${ }^{\mathrm{NS}}$ Nonsignificant estimate. 
Table 2. Mean monthly turf quality scores and least-square differences (LSD) for the 27 crested wheatgrass half-sib families (HSF) and six control cultivars (Cody buffalograss, Fults alkaligrass, Gazelle tall fescue, Manhattan 3 perennial ryegrass, Midnight Kentucky bluegrass, and RoadCrest crested wheatgrass) managed under deficit irrigation from 2000 to 2001.

\begin{tabular}{|c|c|c|c|c|c|c|c|c|}
\hline Genotype & April & June & Early July & Late July & Aug. & Sept. & Oct. & Mea \\
\hline HSF-1 & 4.9 & 2.4 & 3.4 & $3.9^{z}$ & 4.7 & 5.0 & 5.9 & 4.2 \\
\hline HSF-3 & 4.3 & 2.5 & 3.1 & 3.4 & 3.9 & 4.3 & 5.1 & 3.7 \\
\hline HSF-4 & 4.3 & 2.0 & 2.8 & 3.0 & 3.5 & 3.7 & 4.9 & 3.4 \\
\hline HSF-5 & 3.5 & 2.0 & 2.8 & 2.9 & 3.2 & 3.6 & 4.5 & 3.1 \\
\hline HSF-6 & 4.7 & 2.2 & 3.2 & 3.7 & 4.5 & 4.8 & 5.1 & 3.9 \\
\hline HSF-8 & 4.8 & 2.4 & 3.5 & 3.7 & 4.4 & 4.7 & 5.5 & 4.0 \\
\hline HSF-10 & 4.6 & 2.4 & 3.6 & 3.8 & 4.7 & 5.2 & 5.5 & 4.0 \\
\hline HSF-12 & 4.3 & 2.6 & 3.3 & 3.6 & 4.0 & 4.2 & 5.0 & 3.8 \\
\hline HSF-13 & 4.9 & 2.1 & 3.0 & 3.2 & 3.2 & 3.6 & 4.8 & 3.5 \\
\hline HSF-15 & 4.3 & 2.2 & 2.9 & 3.1 & 3.2 & 3.9 & 5.1 & 3.4 \\
\hline HSF-17 & 4.3 & 2.1 & 2.9 & 3.1 & 3.9 & 4.1 & 4.7 & 3.5 \\
\hline HSF-19 & 4.3 & 2.4 & 3.4 & 3.4 & 3.5 & 3.8 & 4.9 & 3.6 \\
\hline HSF-20 & 5.0 & 2.8 & 3.7 & 4.4 & 4.8 & 5.1 & 6.0 & 4.4 \\
\hline HSF-21 & 4.4 & 1.9 & 2.7 & 3.0 & 3.1 & 3.5 & 4.5 & 3.4 \\
\hline HSF-22 & 4.7 & 2.4 & 3.4 & 3.8 & 4.1 & 4.2 & 5.1 & 3.9 \\
\hline HSF-23 & 4.4 & 2.9 & 3.9 & 4.2 & 5.2 & 5.3 & 5.7 & 4.4 \\
\hline HSF-25 & 4.4 & 2.0 & 2.8 & 3.0 & 3.5 & 4.1 & 4.7 & 3.4 \\
\hline HSF-26 & 4.6 & 2.0 & 2.3 & 2.6 & 2.9 & 3.3 & 4.2 & 3.0 \\
\hline HSF-28 & 4.8 & 2.2 & 3.0 & 3.0 & 3.5 & 3.8 & 4.9 & 3.6 \\
\hline HSF-30 & 4.4 & 1.7 & 2.1 & 2.4 & 2.7 & 3.3 & 4.5 & 3.1 \\
\hline HSF-31 & 4.6 & 2.3 & 3.2 & 3.8 & 4.5 & 4.8 & 5.3 & 4.0 \\
\hline HSF-33 & 4.5 & 1.8 & 2.4 & 2.6 & 3.0 & 3.6 & 4.7 & 3.2 \\
\hline HSF-34 & 4.4 & 2.2 & 2.9 & 3.3 & 3.7 & 4.0 & 4.7 & 3.5 \\
\hline HSF-35 & 4.1 & 2.2 & 3.0 & 3.0 & 3.4 & 3.8 & 4.5 & 3.4 \\
\hline HSF-36 & 4.7 & 2.1 & 2.8 & 3.0 & 3.3 & 3.5 & 4.5 & 3.4 \\
\hline HSF-37 & 4.9 & 2.4 & 3.0 & 3.6 & 4.0 & 4.3 & 5.2 & 3.8 \\
\hline HSF-39 & 4.6 & 2.1 & 2.8 & 3.4 & 4.0 & 4.2 & 4.4 & 3.7 \\
\hline HSF Mean & 4.5 & 2.2 & 3.0 & 3.3 & 3.8 & 4.1 & 5.0 & 3.6 \\
\hline Cody & 1.0 & $6.4^{\mathrm{y}}$ & $6.8^{y}$ & $6.0^{y}$ & $6.2^{\mathrm{y}}$ & 4.5 & 2.2 & $4.5^{\mathrm{y}}$ \\
\hline Fults & 2.5 & 2.0 & 2.2 & 1.4 & 1.1 & 1.2 & 1.6 & 1.8 \\
\hline Gazelle & $5.6^{\mathrm{y}}$ & $4.9^{y}$ & $5.8^{\mathrm{y}}$ & $5.4^{\mathrm{y}}$ & $5.4^{\mathrm{y}}$ & $4.7^{y}$ & 4.5 & $5.1^{\mathrm{y}}$ \\
\hline Manhattan 3 & 5.0 & $4.4^{y}$ & $5.0^{\mathrm{y}}$ & $5.6^{y}$ & $5.4^{y}$ & $5.1^{\mathrm{y}}$ & 4.9 & $4.7^{\mathrm{y}}$ \\
\hline Midnight & $6.6^{\mathrm{y}}$ & $6.9^{y}$ & $5.8^{\mathrm{y}}$ & $4.7^{y}$ & 3.7 & 4.2 & 4.4 & $5.0^{\mathrm{y}}$ \\
\hline RoadCrest & 3.5 & 1.8 & 2.9 & 3.0 & 3.3 & 3.8 & 4.7 & 3.2 \\
\hline LSD $5 \%$ & 0.8 & 0.5 & 0.5 & 0.6 & 0.7 & 0.6 & 0.7 & 0.4 \\
\hline
\end{tabular}

${ }^{\mathrm{z}}$ Italicized scores were higher than the HSF mean score for the month based on the corresponding LSD value $(5 \%)$.

${ }^{\mathrm{y}}$ Indicates control cultivars exhibiting higher turf quality than the HSF mean score based on the corresponding LSD value $(5 \%)$.

HSFs 20 and 23, outperformed the halfsib family mean in each month but April (Table 2). These two families were generally the best and performed favorably with the control cultivars from late July/August through October, including the overall study mean scores (Table 2). In September and October, these half-sib families (with some others) performed at least as well, if not better, than each of the control cultivars.

Based on the assumption of an acceptable turf quality being 5 or greater, the best halfsib families would have acceptable, or close to acceptable, quality only in April and then from August to October. Thus, it is unlikely that crested wheatgrass, at least at this point, would be a viable option for replacing common turf species in most typical turf situations, including home lawns, athletic fields, and so on. This is particularly true when considering the excellent performance of the buffalograss entry throughout the months of the study (Table 2). Buffalograss is considered a strong candidate as a lower waterrequiring turf for many areas of the United States, including the intermountain region (Johnson, 2000; Shearman et al., 2004). Although 'Cody' buffalograss had poor per- formance during the months of April and October, it had very high, and often the best, performance during the other months. However, in very water-limited situations or for individuals desiring lower-water requiring turfs, crested wheatgrass might be a good option, but the most likely impact of crested wheatgrass as a turf will remain in lowmaintenance areas such as roadsides, runways, and conservation areas (Feldhake et al., 1983). Other possibilities might include golf course roughs, nature parks, and other similar areas in the intermountain United States.

Genotypic correlations among monthly turf quality scores. Even for truly lowmaintenance situations, plant material with high turf quality is desirable. Based on the previously mentioned heritabilities, there was strong evidence that turf quality could be improved in this population (Table 1). However, the question remained how to best select for the improvement of turf quality in crested wheatgrass, i.e., how can quality best be improved across the growing season and at what point in the growing season should selection occur? To answer these questions, the study investigated the relationship among the monthly turf quality scores using genotypic correlations. If genotypic correlations were sufficiently high among the monthly turf quality scores, then the likelihood of success of a selection program based on a single, or a few, time points rather than the entire growing season would be substantially improved.

Genotypic correlations indicate the extent that the underlying genetics influencing each of the traits are the same (Falconer and Mackay, 1996). In this study, with the exception of April, likely as a result of April's nonsignificant estimation of genetic variation, genotypic correlations between monthly and overall mean scores were very high (data not shown) with the smallest estimate being 0.95 between early and late July. Therefore, it was apparent that the genetics underlying turf quality in this crested wheatgrass population had a very high level of commonality from month to month. The high genotypic correlations among each of the monthly scores and among the monthly scores and the overall mean scores suggested that selection during any of the months, except April, would result in improved turf quality during each of the months and for the overall turf quality across the entire summer. Thus, selection for improved crested wheatgrass turf quality could take place during any of the months of the growing season.

\section{Literature Cited}

Asay, K.H. and K.B. Jensen. 1996. Wheatgrasses, p. 691-724. In L.E. Moser, D.R. Buxton, and M.D. Casler (eds.). Cool-season grasses. Agron. Monogr. 34. ASA, CSSA, and SSSA, Madison, WI.

Asay, K.H., K.B. Jensen, W.H. Horton, D.A. Johnson, N.J. Chatterton, and S.A. Young. 1999. Registration of 'RoadCrest' crested wheatgrass. Crop Sci. 39:1535.

Bushman, B.S., B.L. Waldron, J.G. Robins, and K.B. Jensen. 2007. Color and shoot regrowth of turf-type crested wheatgrass managed under deficit irrigation. Online. Appl. Turf. Sci. 11 Sept. 2007. <http://www.plantmanagement network.org/sub/ATS/research/2007/seeding>.

Diesburg, K.L., N.E. Christians, R. Moore, B Branham, T.K. Danneberger, Z.J. Reichler, T. Voigt, D.D. Minner, and R. Newman. 1997. Species for low-input turf in the U.S. Upper Midwest. Agron. J. 89:690-694.

Falconer, D.S. and T.F.C. Mackay. 1996. Introduction to quantitative genetics. 4th ed. Longman Group Ltd., Essex, UK.

Feldhake, C.M., R.E. Danielson, and J.D. Butler. 1983. Turfgrass ET. I. Factors influencing rate in urban environments. Agron. J. 75: 824-830.

Gibeault, V.A., J.L. Meyer, R. Autio, and R. Strohman. 1989. Turfgrass alternatives with low water needs. Calif. Agr. 43:20-22.

Hanks, J.D., P.G. Johnson, and B.L. Waldron. 2006. Recommended seeding rates for reducedmaintenance, turf-type wheatgrasses. Online. Appl. Turf. Sci. 11 Sept. 2007. <http:// www.plantmanagementnetwork.org/sub/ATS/ research $/ 2007 /$ seeding $>$.

Hanks, J.D., B.L. Waldron, P.G. Johnson, K.B. Jensen, and K.H. Asay. 2005. Breeding CWG-R 
crested wheatgrass for reduced-maintenance turf. Crop Sci. 45:524-528.

Hill, R.W. and K.L. Kopp. 2002. Turfgrass water use in Utah. Utah St. Univ. Ext. Pub. ENGR/ BIE/WM-36.

Holland, J.B. 2006. Estimating genotypic correlations and their standard errors using multivariate restricted maximum likelihood estimation in SAS Proc MIXED. Crop Sci. 46:642-654

Holland, J.B., W.E. Nyquist, and C.T. CervantesMartinez. 2003. Estimating and interpreting heritability for plant breeding. Plant Breed. Rev. 22:9-111.

Johnson, P.G. 2000. An overview of North American native grasses adapted to meet the demand for low-maintenance turf. Diversity. 16:40-41.

Kirk, L.E. 1932. Crested wheatgrass. Univ. Saskatchewan Agr. Ext. Bull. 54.

Littell, R.C., G.A. Milliken, W.W. Stroup, and R.D. Wolfinger. 1996. SAS ${ }^{\circledR}$ system for mixed models. SAS Institute, Cary, NC.
Meyer, W.A., B.L. Rose, J.M. Johnson-Cicalese, and C.R. Funk. 1984. Registration of 'Midnight' Kentucky bluegrass. Crop Sci. 24:822-823.

Nguyen, H.T. and D.A. Sleper. 1983. Theory and application of half sib matings in forage grass breeding. Theor. Appl. Genet. 64:187-196.

Nyquist, W.E. 1991. Estimation of heritability and prediction of selection response in plant populations. Crit. Rev. Plant Sci. 10:235-322.

Robins, J.G., B.L. Waldron, D.W. Cook, K.B Jensen, and K.H. Asay. 2006. Evaluation of crested wheatgrass managed as turfgrass. Online. Appl. Turf. Sci. 11 Sept. 2007. $<$ http://www.plantmanagementnetwork.org/ sub/ATS/research/2007/crested>.

Rose-Fricker, C.A., M.L. Fraser, W.A. Meyer, and C.R. Funk. 2002. Registration of 'Manhattan 3' perennial ryegrass. Crop Sci. 42:2213-2214.

SAS Institute. 2006. SAS system for Windows V. 9.1. Cary, NC.

Severmutlu, S., T.P. Riordan, and R.C. Shearman. 2005. Registration of 'Cody' buffalograss. Crop Sci. 45:2122-2123.
Shearman, R.C., T.P. Riordan, and P.G. Johnson. 2004. Buffalograss. In L.E. Moser, B.L. Burson, and L.E. Sollenberger (eds.). Warm-season (C4) grasses. Agron. Monograph. 45. ASACSSA-SSSA Publishers, Madison, WI.

Skogley, R.D. and C.D. Sawyer. 1992. Field research. In D.V. Waddington, R.N. Carrow, and R.C. Shearman (eds.). Turfgrass. Agron. Monogr. 32. ASA, CSSA, and SSSA, Madison, WI.

Stevens, R., S.B. Monson, N. Shaw, E.D. McArthur, G. James, G. Davis, K.R. Jorgensen, and J.N. Davis. 1983. Naming and release of Ephraim crested wheatgrass. Release Notice. USDA For. Serv., Provo, UT.

Waldron, B.L., N.J. Ehlke, D.L. Wyse, and D.J. Vellekson. 1998. Genetic variation and predicted gain from selection for winterhardiness and turf quality in a perennial ryegrass topcross population. Crop Sci. 38:817-822.

Wofford, D.S. and A.A. Baltensperger. 1985. Heritability estimates for turfgrass characteristics in bermudagrass. Crop Sci. 25: 133-136. 